\title{
AAUOKHYB -1 : An excellent Okra hybrid developed by Assam Agricultural University (AAU) suitable for diverse agro-climatic situation of North East India
}

\author{
G. C. Bora* \\ Department of Plant Breeding and Genetics, Assam Agricultural University, Jorhat \\ (Assam), India

\section{G. N. Hazarika} \\ Department of Plant Breeding and Genetics, Assam Agricultural University, Jorhat \\ (Assam), India \\ P. Talukdar \\ Department of Plant Breeding and Genetics, Assam Agricultural University, Jorhat \\ (Assam), India \\ *Corresponding author. E-mail : gobin_bora@yahoo.co.in

\begin{abstract}
A hybrid development programme on okra (Abelmoschus esculentus) was undertaken at the Assam Agricultural University (AAU), Jorhat. The work included collection and evaluation of okra germplasm, identification of parents for hybridization, selfing of identified parental lines, making crosses and production of hybrid seeds, testing of hybrids for yield and resistance to Yellow Vein Mosaic Virus (YVMV) disease, adaptability under diverse agro-climatic condition and testing in all India trials. The programme resulted in development and identification of excellent Okra hybrid AAUOKHYB-1 in 2017. The performance of the hybrid was very good under diverse agro-climatic conditions yielding about $162.0 \mathrm{q} / \mathrm{ha}$ fruit yield which is $32.5 \%$ higher than the best commercial check Arka Anamika. The hybrid showed resistant $(R)$ reaction to YVMV disease. A wide range of heterosis upto $43 \%$ was exhibited by the hybrid in different vegetable research centres of the country as compared to the best check variety.
\end{abstract}

Keywords : AAUOKHYB-1, Diverse condition, Heterosis, Hybrid ,YVMV

\section{Article Info}

DOI:10.31018/jans.v10i2.1763 Received: October 26, 2017

Revised: January 29, 2018

Accepted: April 28, 2018

\section{How to Cite}

Bora, G. C. et al. (2018) AAUOKHYB -1 : An excellent Okra hybrid developed by Assam Agricultural University (AAU) suitable for diverse agro-climatic situation of North East India. Journal of Applied and Natural Science, 10 (2): 672 - 675

\section{INTRODUCTION}

Bhindi, okra or ladies finger (Abelmoschus esculentus) is an important vegetable crop grown in Assam, North Eastern states and India as a whole. The crop is grown for many purposes including green fruits for culinary purpose and dry fruits, stems and leaves for preparation of dry powder to be used as clarificant of jaggery. Further, the dry stems are used as firewood by the poor people. In home consumption, India tops in the world with an availability of $5.849 \mathrm{mt}$ green fruits from an area over 0.511 mha (Annonymous, 2016a). In addition, the immature fresh fruits from India are exported to its neibouring countries like Singapore, Mauritus, Malayasia, Srilanka and Bangladesh. Further countries like Bahrain, Quarter, Kuwait, Saudi Arabia, Muscat, Iran and Abu Dhabi are some upcoming potential markets of this crop for exports (Annonymous, 2016b). The genus Abelmoschus is Asiatic in origin and the species Abelmoschus esculentus constitutes a wide range of cultivars. India, Ethiopia, West Africa and Tropical Asia are considered possible countries of origin (Kalloo, 1993). It is considered as a polyploid $(2 n=130)$ in nature. Dhankhar and Mishra (2004) described the objectives of okra breeding for Indian condion. Although many varieties and hybrids were available in India but varieties with high yield potential and resistance to YVMV disease are limited. In view of this, a hybrid development programme was undertaken with the objectives to develop hybrid bhindi with high yielding potential and resistance to YVMV disease.

\section{MATERIALS AND METHODS}

Altogether 50 germplasm lines maintained at AAU, Jorhat were sown at Sugarcane Research Station (SRS), Buralikson in the month of June, 2004 during Kharif season. All recommended practices were followed to raise a healthy crop. The experiment was conducted in a Randomized Block Design and all desirable characteristics including fruit yield and its components were recorded along with observation for YVMV incidence under natural field conditions. Ten (10) best lines were identified based on fruit yield recorded from 
$1^{\text {st }}$ to $8^{\text {th }}$ harvest and reaction to YVMV disease from July to September. The parental lines selected for making crosses were Shagun, P-7, Pusa Sawani, KO and PP for higher fruit yield per plant and S-51, PB-226, DSN-1, PK and AOL 03-1 for resistance to YVMV disease. All the parents were crossed in all possible combinations during 2005 and the experimental hybrids were grown in the subsequent year in 2006. From the study of combining ability, 15 heterotic hybrids were identified out of which the best one was identified to be Shagun x S-51. The hybrid was evaluated in the 3 experimental sites viz., SRS, Buralikson ; $A A U$, Jorhat and Regional Agril. Research Station (RARS), Gossaigaon in both summer and rainy season. In the experiments, two checks viz., HOK-152 (hybrid) and Arka Anamika (commercial variety) were used for comparision. Subsequently, the hybrid was tested under various agro-climatic conditions through different KVKs of AAU. The parents were selfed for 3 generations and hybrid seed production was done under net house conditions using the selfed parents. The hybrid was included in the AICRP trial and tested in various AICRP Centres during 2011 to 2014 throughout the country. Grading of the tested entries for YVMV reaction from highly resistant to highly susceptible following the scale provided by the AICRP (Annual Report, 1990). The hybrid was recognized by the AAU and identified for release in the state of Assam (Annonymous, 2017).

\section{RESULTS AND DISCUSSION}

The performance of the hybrid AAUOKHYB-1 is presented in table-1. From the table it is observed that there was increase in fruit yield in the experimental as well as in the farmer's fields by $47 \%$ as compared to the best check variety Arka Anamika. The duration to fruit picking was also 5 days earlier in Jorhat district than the check varieties. The testing of the hybrid in different agro-climatic zones of Assam resulted $32.5 \%$ increase in yield over the check varieties. The extent of heterosis

Table 1. Performance of Okra hybrid 'AAUOKHYB-1' in different zones of Assam (2009 to 2011).

\begin{tabular}{|c|c|c|c|c|c|c|c|c|c|}
\hline \multirow[t]{3}{*}{ Hybrids } & \multicolumn{8}{|c|}{ Fruit yield (q/ha) } & \multirow{3}{*}{$\begin{array}{l}\text { Duration } \\
\text { 1st } \\
\text { picking }\end{array}$} \\
\hline & \multicolumn{3}{|c|}{ AAU, Jorhat } & \multicolumn{4}{|c|}{ Farmers' Fields at Jorhat } & \multirow[t]{2}{*}{ Mean } & \\
\hline & 2009 & 2010 & 2011 & Lahing & & $\begin{array}{l}\text { Sah- } \\
\text { puria }\end{array}$ & $\begin{array}{l}\text { Dhekia- } \\
\text { juli }\end{array}$ & & \\
\hline AAUOKHYB-1 & 125.6 & 165.6 & 167.3 & 156.2 & & 165.4 & 145.2 & 154.2 & $40-45$ days \\
\hline HOK-152(Hyb) & 112.4 & 97.0 & 96.7 & - & & - & - & 102.0 & - \\
\hline Arka Anamika (BCV) & 70.5 & 88.7 & 115.4 & 125.4 & & 120.3 & 105.4 & 104.3 & $45-50$ days \\
\hline Hybrids & UBVZ & LBVZ & NBPZ & & $\mathbf{H Z}$ & Mean & $\begin{array}{l}\% \text { in } \\
\text { over } \mathrm{E}\end{array}$ & $\begin{array}{l}\text { rease } \\
C_{*}^{*}\end{array}$ & $\begin{array}{l}\text { Consumer } \\
\text { preference }\end{array}$ \\
\hline AAUOKHYB-1 & 154.2 & 185.2 & 111.1 & & 197.5 & 162.0 & 32.5 & & Good(88 - 90\%) \\
\hline HOK-152 (Hyb) & 102.0 & - & - & & - & 102.0 & - & & - \\
\hline Arka Anamika (BCV) & 104.3 & - & $85.0 / 1$ & 38.9 & 161.0 & 122.3 & & & Good(84 - 87\%) \\
\hline
\end{tabular}

${ }^{*} \mathrm{BCC}$ (Best commercial check) is Arka Anamika.

Table 2. Descriptor for Okra hybrid 'AAUOKHYB-1'.

\begin{tabular}{|c|c|c|c|c|c|}
\hline S.N. & Characteristics & AAUOKHYB-1 & S. N. & Characteristics & $\begin{array}{l}\text { AAUOK } \\
\text { HYB-1 }\end{array}$ \\
\hline 1 & Stem colour & Reddish green & 18 & Fruit length $(\mathrm{cm})$ & 14 \\
\hline 2 & $\begin{array}{l}\text { Stem : intensity of green } \\
\text { Colour }\end{array}$ & $60 \%$ & 19 & $\begin{array}{l}\text { Fruit diameter (at mid length) } \\
(\mathrm{cm})\end{array}$ & 1.0 \\
\hline 3 & Leaf blade : depth of lobing & High & 20 & Fruit surface between ridges & Smooth \\
\hline 4 & No. of nodes at first flowering & $5^{\text {th }}$ & 21 & Fruit pubescence & Medium \\
\hline 5 & Days to $50 \%$ flowering & 38 days & 22 & Fruit : constriction of basal part & Low \\
\hline 6 & Leaf blade length (cm) & 16 & 23 & Fruit shape of apex & Blunt \\
\hline 7 & Leaf blade width $(\mathrm{cm})$ & 23 & 24 & Fruit : number of locules & 6 \\
\hline 8 & Leaf blade : serration of margin & Medium & 25 & Plant : number of branches & 5 \\
\hline 9 & Leaf blade : colour between veins & Dark green & 26 & $\begin{array}{l}\text { Stem diameter (at } 10 \mathrm{~cm} \text { above } \\
\text { the ground level) }(\mathrm{cm})\end{array}$ & 3 \\
\hline 10 & Intensity of colour between veins & High & 27 & Plant height $(\mathrm{cm})$ & 172 \\
\hline 11 & Vein colour & Light green & 28 & $\begin{array}{l}\text { Fruit length of physio-logically } \\
\text { mature fruit }(\mathrm{cm})\end{array}$ & 20 \\
\hline 12 & Petiole length $(\mathrm{cm})$ & 17 & 29 & $\begin{array}{l}\text { Fruit diameter (at mid length) } \\
(\mathrm{cm})\end{array}$ & 2.5 \\
\hline 13 & Flower : petal colour & Yellowish white & 30 & Consumer preference & good \\
\hline 14 & Petal base colour (purple) & Purple & 31 & No. of ridges & $5-6$ \\
\hline 15 & Flower length $(\mathrm{cm})$ & 6 & 32 & No. of fruits per plant & 22 \\
\hline 16 & $\begin{array}{l}\text { Flower: diameter (at the top of } \\
\text { flower) }(\mathrm{cm})\end{array}$ & 5 & 32 & Single fruit weight $(\mathrm{g})$ & 16.3 \\
\hline \multicolumn{3}{|c|}{ IC number female parent : IC-0620644 } & \multicolumn{2}{|c|}{ IC Number male parent : IC-0620645 } & 8 \\
\hline
\end{tabular}


Bora G. C. et al. / J. Appl. \& Nat. Sci. 10 (2): 672 - 675 (2018)

Table 3. Reaction of the okra hybrid AAUOKHYB-1 to YVMV disease and shoot and fruit borer.

\begin{tabular}{llll}
\hline Bariety & $(\%)$ YVMV incidence & Reaction Grade & Shoot and fruit borer \\
\hline AAUOKHYB-1 & 15 & $\mathrm{R}$ & Low \\
Pusa Sawani & 45 & MS & High \\
HOK-152 (Hyb) & 28 & MR & Medium \\
Arka Anamika (BCV) & 30 & MR & Medium \\
\hline
\end{tabular}

Table 4. Performance of okra hybrid AAUOKHYB-1 under waterlogging condition at RARS, Gossaigaon.

\begin{tabular}{lll}
\hline Variety & Fruit yield (q/ha) & Remark \\
\hline AAUOKHYB-1 & 185 & Waterlogging persisted for 5-7 days at \\
Pusa Sawani & 10 & seedling and active vegetative stage. \\
HOK-152 $(\mathrm{Hyb})$ & 150 & \\
Arka Anamika (BCV) & 120 & \\
\hline
\end{tabular}

Table 5. Heterosis(\%) for fruit yield of AAUOKHYB-1 over the best check at various centres.

\begin{tabular}{lll}
\hline Centres & $\begin{array}{l}\text { AAUOKHYB-1 } \\
(\mathbf{2 0 1 1 / O K H Y B - 1 0 )}\end{array}$ & Best Check \\
\hline IVT Trials & & \\
\hline Allahabad & $10.4 \%$ & PS \\
Akola & $10.6 \%$ & HOK-152 \\
Sabour & $4.1 \%$ & HOK-152 \\
Hyderabad & $3.8 \%$ & HOK-152 \\
IIHR & $7.3 \%$ & HOK-152 \\
\hline AVT-I Trials & & \\
\hline Allahbad & $8.4 \%$ & AA \\
Rahuri & $21.5 \%$ & AA \\
Jabalpur & $43 \%$ & AA \\
Coimbatore & $11.2 \%$ & HOK-152 \\
Ludhiana & $13.3 \%$ & HOK-152 \\
Hyderabad & $5.7 \%$ & HOK-152 \\
\hline AVT-II Trials & & \\
\hline IIVR & $1.8 \%$ & HOK-152 \\
Parbhani & $0.94 \%$ & HOK-152 \\
Rahuri & $26.8 \%$ & HOK-152 \\
Jorhat & $13.5 \%$ & HOK-152 \\
Ludhiana & $4.2 \%$ & HOK-152 \\
CARI (Goa) & $14.1 \%$ & PS \\
\hline
\end{tabular}

and performance of some okra hybrids under Assam condition have also been reported in earlier studies (Bora et al., 2008 ; Bora et al, 2009). The yield increase in the hybrid was due to more branches and more number of fruits per plant. The internode length was also less with more number of nodes. Similar kind of results were reported by Sood and Sharma (2001), Singh and Kumar (2005), and Yadav et al. (2007) in different hybrids. The descriptor of the hybrid is presented in table 2.

The incidence of YVMV disease in the AAU hybrid was found to be the lowest (15\%) as compared to other check varieties viz., HOK-152 hybrid (28\%), Arka Anamika (30\%) and Pusa Sawani (45\%) under natural field condition (Table 3). The AAUOKHYB-1 could be graded as resistant (R), Pusa Sawani as moderately susceptible (MS) and other two as moderately resistant as per disease scale. It showed low shoot and fruit borer infestation also. Although the right season for growing okra in Assam is summer till the end of July (Annonymous, 2009), the hybrid was also tested

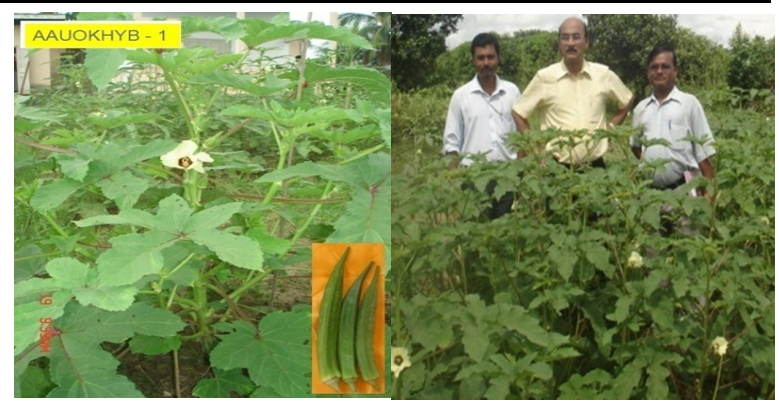

Photo 1. 'AAUOKHYB-1' Photo 2. Director of hybrid of okra. Research(Agrl) with the breeder and farm manager visiting the hybrid plot of okra.

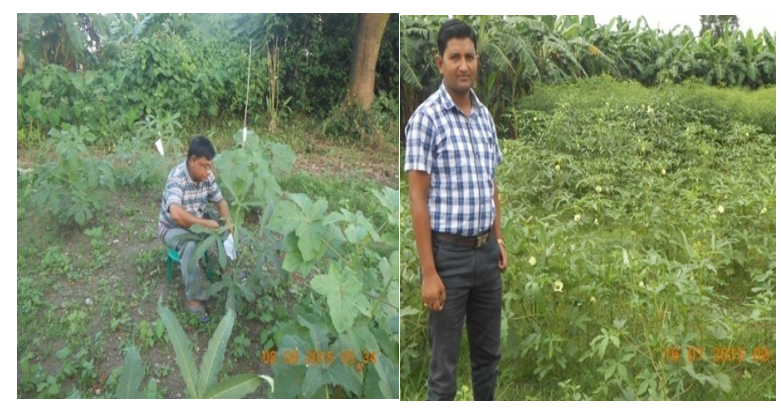

Photo 3.Breeder making Photo 4. Demonstration the crossesin okra.

plot of hybrid at Gossaigaon .

in rainy season because in the end of rainy season during Oct. - Nov., the price of okra fruit is quite high resulting in higher profit. The hybrid showed higher fruit yield (185 $\mathrm{q} / \mathrm{ha})$ as compared to the best check HOK-152 (150 q/ha) under waterlogging condition also (Table 4). This indicated that the hybrid would be suitable for high rainfall area also.

Table 5 shows the results of the AICRP trials conducted in various centres throughout the country. From the table it is apparent that the hybrid showed better performance over the best check variety/hybrid. Out of total 55 trials, AAUOKHYB-1 showed higher performance in 17 trials and was at per with the best check in 16 trials. The Centres where the hybrid showed better performance than the best check were Allahabad, Akola, Savour, 
Bora G. C. et al. / J. Appl. \& Nat. Sci. 10 (2): 672 - 675 (2018)

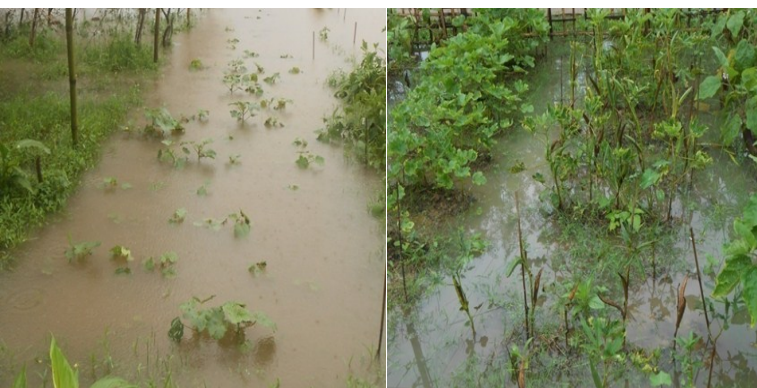

Photo 5.Demostration plot Photo 6. Waterlogging in of okra at Gossaigaon. hybrid okra plot at various crop growth stages.

Hyderabad and Bangalore in IVT; Allahabad, Rahuri, Jabalpur, Coimbatore, Ludhiana and Hyderabad in AVT-I ; and IIVR, Parbhani, Rahuri, Jorhat, Ludhiana and CARI (Goa) in AVT-II. In leguminous (bean) and malvaceous (okra) crops, heterosis observed is usually less and hence more than $10 \%$ heterosis may be considered as standard for the purpose of recommendation (Kumar, 2006; Singh et al., 2013). The centres showing $>10 \%$ higher yield than the best check were Allahabad, Akola, Rahuri, Jabalpur, Coimbatore, Ludhiana, Jorhat and CARI. Hence the hybrid AAUOKHYB-1 may be considered for recommendation/release for the states of UP, Maharastra, MP, TN, Punjab, Assam and Goa in India.

\section{Conclusion}

The hybrid AAUOKHYB-1 which has performed well not only in Assam but out yielded the best commercial check Pusa Sawani, Arka Anamika and hybrid HOK-152 by more than $10 \%$ in various states like UP, Maharastra, MP, TN, Punjab, Assam and Goa also. The hybrid showed resistant reaction to YVMV disease and good performance under waterlogging condition also. The consumer preference is also good. The parental lines of the hybrid has been conserved in NBPGR, New Delhi, India.

\section{ACKNOWLEDGEMENTS}

The authors thankfully acknowledge the help and cooperation received from the Department of Plant Breeding and Genetics, Department of Horticulture, Department of Plant Pathology, Assam Agiculture University (AAU), Jorhat, Assam and as a whole from the AAU Authority for conducting the study. The financial assistance provided by the ICAR, New Delhi through the Project Coordinator, AICRP on Vegetable Crops, IIVR, Varanasi is thank-fully acknowledged. The scientists of different AICRP (VC) Centres are cordially acknowl- edged for their fruitful work leading to identification of the hybrid.

\section{REFERENCES}

Annual Report (1990). Report of the Project Directorate of Vegetable Research presented at the XIth Workshop of the All India Coordinated Vegetable Improvement Project, held at YSPUHF, Solanduring June, (1990) pp. $225-44$.

Annonymous (2009). 'Package of Practices of Horticultural Crops of Assam' published by Dept. of Agriculture, GoA, Guwahati and AAU, Jorhat.

Annonymous (2016a) . www.agricoop.nic.in.

Annonymous (2016b). Fresh fruits and vegetables exported from India. www.apeda.gov.in.

Annonymous, (2017). Anand Agriculture University (AAU )Newsletter, Anand (2016-17).

Bora, G. C. , Devi, J. , Baruah S. J. N., Gogoi S. and Paswan L.2009. Performance of Okra (Abelmoschus esculentus) hybrids for yield and component traits in the North East India. Abstracts of the contributed and invited papers (Abstract No. 1.1 - P47) of the international conference on Horticulture $(\mathrm{ICH}-2009)$ on "Horticulture for livelihood security and economic growth" held in Bangalore wef 9 th to $12^{\text {th }}$ Nov.,pp 51 .

Bora, G. C., Hazarika, G. N., and Buragohain, S.K. 2008. Heterosis for yield and its components in okra. Abstracts of the "Regional Workshop on accelerating growth in Horticulture sector - Challenges and opportunities for North East India." Held at the Assam Agricultural University, Jorhat, Assam (India) from $19^{\text {th }}$ and $20^{\text {th }}$ August, 2008. Abstract. No. 13 Technical session II, pp nil.

Dhankhar, B. S. and Mishra J. P. (2004). Objectives of Okra breeding, In Hybrid Vegetable Development. Eds by P K Singh, S K Dasgupta and S K Tripathi. Published by Food Product Press 10 Allice Street, Bimghamton, New York, USA.

Kalloo, G. (1993). Prospects and potential in heterosis breeding in crop plants eds M M Verma, D S Virk, G S Chahal and B S Dhillon pp.140.

Kumar, N. (2006). Bhendi : In Breeding of Horticultural Crops : Principles and Practices. New India Publishing Agency, New Delhi 110088 (INDIA).

Singh, B., Goswami, A. and Kumar, M.(2013). Estimation of heterosis in okra for fruit yield and its components through diallel mating system. Indian J. Hort. 70(4) : 595-598.

Singh, S.P. and Kumar, S. 2005. Heterosis and inbreeding depression for plant yield and its components in okra [Abelmoschus esculentus (L.) Moench]. Curr. Res. J.8: $77-80$

Sood, Sonia and Sharma, S.K. 2001. Heterosis and gene action for economic traits in okra. Dia- mond Jubilee Symp. Poster Abstr.Nov. 6-9,2001 held at New Delhi, pp. 154.

Yadav, J.R., Bhargava, L., Kumar, S., Mishra, G. Alok Yadav, Parihar, N.S. and Singh, S.P. 2007. Useful heterosis for yield and its components in okra [Abelmoschus esculentus (L.) Moench]. Prog. Agric.7: 38-41. 